\title{
PANCASIla AND LAW REVIEW
}

Doktoral Ilmu Hukum, Fakultas Hukum, Universitas Lampung, Bandar Lampung, Lampung, Indonesia.

Volume 2 Issue 2, July-December 2021: pp: 109-120 http://jurnal.fh.unila.ac.id/index.php/plr P-ISSN: 2723-262X E-ISSN: 2745-9306

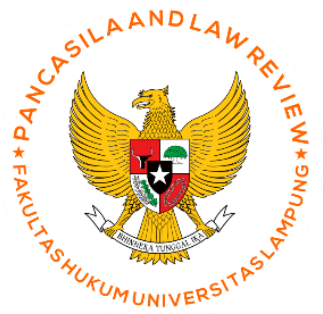

\section{Population and Civil Registration Service of Bandar Lampung City's Digital Bureaucratic System in Realizing an Effective and Efficient Government}

\author{
Sondika Ragani \\ Universitas Padjadjaran, Indonesia \\ sondikaragani5@gmail.com \\ Adrian E. Rompis \\ Universitas Padjadjaran, Indonesia \\ radrie@gmail.com \\ Santi Hapsari Dewi Adikancana \\ Universitas Padjadjaran, Indonesia \\ santi.hapsari@unpad.ac.id
}

Submitted: Jul 5, 2021; Reviewed: Nov 8, 2021; Accepted: Nov 10, 2021

\begin{tabular}{|c|c|}
\hline Article's Information & Abstract \\
\hline keywords: & Abstract \\
\hline $\begin{array}{l}\text { Bureaucracy; Government; } \\
\text { Society. }\end{array}$ & $\begin{array}{l}\text { Nowadays, technological developments cannot be } \\
\text { avoided. Technological developments in this era are } \\
\text { to facilitate every human activity. The development of }\end{array}$ \\
\hline $\begin{array}{l}\text { DOI: } \\
\text { https://doi.org/10.25041/plr.v2i } \\
2.2448\end{array}$ & $\begin{array}{l}\text { technology today is marked by the number of } \\
\text { applications that can facilitate the community's } \\
\text { affairs. An example is the application of the } \\
\text { Community Online Service from the Population and } \\
\text { Civil Registry Office of Bandar Lampung City called } \\
\text { Pelayanan Online Masyarakat Duduk Manis (Permen } \\
\text { Manis). This application is expected to help } \\
\text { community services to help manage population } \\
\text { documents and realize an effective and efficient } \\
\text { government. The problem identified is the application } \\
\text { of digital bureaucracy in the Population and Civil } \\
\text { Registration Office, or Dinas Kependudukan dan } \\
\text { Pencatatan Sipil (Disdukcapil) of Bandar Lampung } \\
\text { City realizes an effective and efficient government? } \\
\text { The research uses normative legal research by } \\
\text { collecting and analyzing secondary data. by looking } \\
\text { to the public's comments, especially on Permen Manis } \\
\text { application users in Bandar Lampung's Civil Registry }\end{array}$ \\
\hline
\end{tabular}


Office. By this article the researcher hope the government in Bandar Lampung could improve the services towards the people in Bandar Lampung.

\section{A. Introduction}

The development of communication and information technology is happening in Indonesia today is unavoidable. This phenomenon is a necessity, where countries are increasingly integrated into international information and technology systems. One of the impacts of integrating this information and technology system is the increasing need for reliable human resources to accommodate changes in the domestic and public environment by utilizing these advances in technology and information. The implication will be apparent, especially in reducing the need for unreliable human resources, which will automatically be replaced by reliable human resources who understand their work using increasingly sophisticated information and technology systems. ${ }^{1}$

Public demands regarding the need to improve the performance of the public bureaucracy had become a public agenda when the lower public trust followed the fall of the New Order regime in the government/public bureaucracy in terms of providing public services to the community. The public bureaucracy's confidence crisis was marked by the flow of protests and demonstrations by various components of society against the public bureaucracy at both the regional and central levels. The occupation of government offices, official residences of regents, mayors, village/nagari heads, and the destruction of various public goods and facilities are common phenomena in the regions. ${ }^{2}$

The crisis of trust in the public bureaucracy is really clear to see, considering it has been an effective instrument for the New Order rulers to maintaining their power. The public bureaucracy, both civilian and military, in the New Order regime has positioned as a tool of rulers rather than public servants. ${ }^{3}$ The interests of the rulers tend to be central to the life and behavior of the public bureaucracy. This is reflected in the public policy process, where rulers have always been the dominant criteria and have often ousted many people when the two did not go hand in hand. So far, the community has had limited opportunities and space to participate in the public policy process. As a result, many public policies and government programs are unresponsive and fail because they do not support the community. ${ }^{4}$

When faced with the process of administering public services with a solid orientation for power, so far, this has made the bureaucracy increasingly distant from its mission to provide a service. ${ }^{5}$ Currently, the quality of public services is still characterized by services that are difficult to access when it comes to taking care of specific permits, unclear fees, and the practice of illegal levies (extortion), indicators of Indonesia's low quality of public services. This is due to the bureaucracy and officials placing themselves as rulers rather than as public servants. In addition, the paradigm built by bureaucrats is still the old paradigm characterized by overbureaucratic, bloated, wasteful, and under-performing. ${ }^{6}$ The development of a paternalistic culture has contributed to the public service system degrade by placing the interests of the

\footnotetext{
${ }^{1}$ B. J. Hodge, William P. Anthony, and Lawrence M. Gales, Organization Theory: A Strategic Approach (New Jersey: Pearson, 2003).

2 Roni Ekha Putera, "E-Government Dan Reformasi Birokrasi Dalam Rangka Peningkatan Pelayanan Publik Di Daerah," Demokrasi 8, no. 1 (2009): 97-98, https://media.neliti.com/media/publications/243823-e-governmentdan-reformasi-birokrasi-dal-06e88185.pdf.

${ }^{3}$ Muhammad Haripin, Chaula Rininta Anindya, and Adhi Priamarizki, "The Politics of Counter-Terrorism in PostAuthoritarian States: Indonesia's Experience, 1998-2018," Defense \& Security Analysis 36, no. 3 (2020): 275-99, https://doi.org/10.1080/14751798.2020.1790807.

${ }^{4}$ Affan Gaffar, Politik Indonesia Transisi Menuju Demokrasi (Yogyakarta: Pustaka Pelajar, 2005).

5 Linsey McGoey, "On the Will to Ignorance in Bureaucracy," Economy and Society 36, no. 2 (2007): 212-35, https://doi.org/10.1080/03085140701254282.

${ }^{6}$ Norman Flynn, Public Sector Management (Chenai, 1990).
} 
political elite and the bureaucracy as the dominant variable in the administration of public services. Political and bureaucratic elites and or those close to them often receive preferential treatment in the administration of public services. Access to services and quality of services often differ depending on proximity to bureaucratic and political elites. As a result, the bureaucracy's behaviour in providing services tends to ignore the community's aspirations and interests.

Bureaucracy is usually called the public sector administration. The function of the bureaucracy is not only as a public service. It also functions as a revenue collection and regional autonomy regulator. ${ }^{7}$ Here, the bureaucracy plays an essential role in realizing state administration to help realize national goals. The dominant position and role of the government bureaucracy demand that the bureaucracy be able to carry out its mission carry out functions, and carry out all activities for which it is responsible with the highest level of efficiency and effectiveness, coupled with service orientation, not power orientation, and displaying functional behaviour.

It is undeniable that today's public services are becoming an increasingly strategic issue. This is because the quality of the performance of the public service bureaucracy has broad implications in various aspects of people's lives. Improving the performance of bureaucratic services in the economic sector, for example, will encourage the creation of a conducive climate for business activities and investment, which in turn will open up wider job opportunities. Not surprisingly, quality public services are indicators of changes in government administration in favour of improving people's welfare.

Therefore, the bureaucracy becomes an important benchmark in assessing the performance of the government to its people. A clean bureaucratic mentality, serving professionally will undoubtedly increase the people's trust in the government. On the other hand, if the bureaucracy is seen as corrupt, picky, and unreliable, the people will naturally distrust the government. To carry out a mental revolution in the bureaucracy, one must first know and understand some of the fundamental values that we still find in our bureaucratic world. First, power-oriented values, Second, high sectoral ego, third, mental bureaucracy, the face of our current bureaucracy is still far from the ideal conditions expected.

Some of these bureaucratic mentalities, according to their causes, still overshadow the figure of the Indonesian bureaucracy. Therefore, the improvements made must touch the system changes and fundamental values. Moreover, in principle, the mental revolution in the bureaucracy is an inseparable part of bureaucratic reform itself. ${ }^{8}$

Bureaucracy can be seen as embedded in formalization, i.e., redefining, reinterpreting reality, and reclassifying its elements, which is focused on increasing the capacity for control and direction, enabling the expansion of the field action of modern institutions. ${ }^{9}$

About the digital bureaucracy as a mental revolution, it is interesting for us to observe. Moreover, the association of advertising companies in Southeast Asia has released some interesting data that clearly illustrates how significant the influence of information technology in Indonesia is. Thus, the Indonesian people now live in an era of information and technology that is all digital and sophisticated. People's lifestyles and lifestyles have also changed.

The digital bureaucracy is a massive force that moves the entire community to be participative, intelligent, innovative. Digital bureaucracy aims to jointly strive to raise the nation's progress, achieve the state's goal. These goals are: protecting the entire Indonesian

\footnotetext{
${ }^{7}$ Gregg G Van Ryzin, Norma M Riccucci, and Huafang Li, "Representative Bureaucracy and Its Symbolic Effect on Citizens: A Conceptual Replication," Public Management Review 19, no. 9 (2017): 1365-79, https://doi.org/10.1080/14719037.2016.1195009.

${ }^{8}$ Yasonna H. Laoly, Birokrasi Digital (Jakarta: PT.Pustaka Alvabet, 2016).

${ }^{9}$ Sandro Serpa and Carlos Miguel Ferreira, "The Concept of Bureaucracy by Max Weber," International Journal of Social Science Studies 7, no. 2 (2019): 12, https://doi.org/10.11114/ijsss.v7i2.3979.
} 
nation, educating the nation's life and all of Indonesia's bloodshed, educating the nation's life. , improve public welfare, and participate in creating world order based on eternal peace and social justice. This is one manifestation of the mental revolution in the digital era: the birth of a digital bureaucracy that is transparent, fair, participatory, accountable, effective, and efficient.

The Population and Civil Registration Service or Dinas Kependudukan dan Pencatatan Sipil (Disdukcapil) of Bandar Lampung City made a breakthrough in serving the community during the COVID-19 pandemic. The Bandar Lampung City Disdukcapil said the service program was named the Online Community Service called Pelayanan Online Masyarakat Duduk Manis (Permen Manis). This innovation is an expansion of service improvement for the community to obtain Population and Civil Registry documents. Access to these services can be obtained through downloading on the Playstore.

The provision of services is a follow-up to the direction of the Mayor of Bandar Lampung, who wants better, faster, efficient, and effective public services. The Disdukcapil of Bandar Lampung City also provides 23 other services through the application, including Identity Card or Kartu Tanda Penduduk (KTP) and Children Identity Card or Kartu Identitas Anak (KIA).

He hopes that an innovation program like this can increase the interest of people who have not yet updated their population documents. ${ }^{10}$

\section{B. Discussion}

\section{The Meaning of Bureaucracy}

Linguistically, the term bureaucracy comes from the French "bureau," which means office or desk, and the Greek "createin", which regulates. Initially, this term was used to refer to a systematic regulated work activity that an office ordered through administrative activities. In the English concept in general, bureaucracy is called civil service. It is also often referred to as the public sector, public service, or public administration. The term bureaucracy is often associated with government organizations, even though the bureaucracy created by Max Weber can occur both in government organizations and non-governmental organizations. In a bureaucratic company, that can happen. Similarly, in a large organization, bureaucracy will occur. In the world of government, the concept of bureaucracy is interpreted as a process and system that is created rationally to guarantee an orderly, definite, and easily controlled work mechanism and system.

Bureaucracy is a vital instrument in a society whose presence is inevitable. Bureaucracy is a logical consequence of accepting the hypothesis that the state has a mission: to prosper its people through the media of bureaucracy. Therefore the state must be directly involved in producing public goods and services needed by its people. ${ }^{11}$ The state is actively involved in the social life of its people; even if necessary, the state decides what is best for its people.

For this reason, the state builds an administrative system that aims to serve people's interests, which is called the bureaucracy. Initially, this term was used to refer to a systematic work activity that is regulated or ordered by an office through administrative activities (Ernawan, 1988). In the English concept in general, bureaucracy is called "civil service". In addition, it is also often referred to as the public sector, public service, or public administration. $^{12}$

The theory of bureaucratic organization develops in the realm of sociology and emphasizes the legal-rational aspect. In this case, it is interpreted as the authority and the role of each

\footnotetext{
${ }^{10}$ Lampung Geh, “Terobosan Pelayanan, Disdukcapil Bandar Lampung Luncurkan Program 'Permen Manis,"” Kumparan, 2021, https://kumparan.com/lampunggeh/terobosan-pelayanan-disdukcapil-bandar-lampungluncurkan-program-permen-manis-1 vbonxeob4l/full.

11 Mark Murphy, "Bureaucracy and Its Limits: Accountability and Rationality in Higher Education," British Journal of Sociology of Education 30, no. 6 (2009): 683-95, https://doi.org/10.1080/01425690903235169.

12 Tri Yuniningsih, Kajian Birokrasi (Semarang: Departemen Administrasi Publik, Universitas Diponegoro, 2019), http://eprints.undip.ac.id/73483/1/BUKU_KAJIAN_BIROKRASI_GABUNGAN.pdf.
} 
element. At the same time, rational refers to a clear goal and set together. One of the proponents of classical organizational theory was Max Weber (21 April 1864-14 June 1920). A German political economist and sociologist. In one of his famous works. The Protestant Ethic and Spirit of Capitalism and The Theory of Social and Economic Organization.

\section{Classic Organisational Theory}

Max Weber created a model of the ideal type of bureaucracy, which explains that a bureaucracy or administration has a definite form. All functions are carried out in rational ways. According to him, the ideal type can compare the bureaucracy between one organization and another. According to Max Weber, the ideal type of rational bureaucracy is carried out in the following ways:

1. Individual officials are personally free but are limited by their positions when they carry out their duties or individual interests in their positions. Officials are not free to use their positions for their personal needs and interests, including their families.

2. The positions are arranged in hierarchical levels from top to bottom and the side. Consequently, there are positions of superiors and subordinates, and some have greater power, and some have less power.

3. The duties and functions of each position in the hierarchy are specifically different from each other.

4. Every official has a contract of office to recognize. The job description of each official is the domain of authority and responsibility under the contract.

5. Each official is selected based on their professional qualifications. Ideally, this is done through a competitive exam.

6. Every official has a salary, including the right to receive a pension following the hierarchy of positions they hold. Each official can decide to leave the job and position per wishes. However, this behaviour will terminate their contract under certain circumstances. $^{13}$

7. There is a clear career development structure with promotions based on seniority and merit under objective considerations.

8. Every official is not justified in carrying out his position and agency's resources for his personal and family interests.

9. Every official is under the control and supervision of a system that is run in a disciplined manner. There must be a principle of certainty from official matters regulated by law, which is usually manifested in various administrative regulations or provisions. ${ }^{14}$

\section{General Principles of Good Governance}

Good governance is constantly evolving, and following global developments, it cannot be only national. The administration of government is to provide public services to the community, which are influenced by the dynamics of politics, economy, developments in information technology, socio-culture, all of which mix and influence government administration.

The administration of government in developed countries is undoubtedly different from developing countries. Several essential factors influence, namely a way of thinking that prioritizes service quality, transparency, integrity, capacity building and is supported by other things that are non-technical but support the realization of good governance. The government administration is determined by the government works and the policies seen through citizens'

\footnotetext{
${ }^{13}$ Sounman Hong, "Representative Bureaucracy and Hierarchy: Interactions among Leadership, Middle-Level, and Street-Level Bureaucracy," Public Management Review 23, no. 9 (2021): 1317-38, https://doi.org/10.1080/14719037.2020.1743346.

${ }^{14}$ Yuniningsih, Kajian Birokrasi.
} 
prosperity. The policies implemented must still be based on the general principal of good governance or Asas-Asas Umum Pemerintahan yang Baik (AAUPB) and applicable laws.

Hotma P. Sibuea stated that AAUPB was born from the practice of state administration and government so that it is not a formal product of a country like a law. AAUPB was born to improve the protection of individual rights. The function of AAUPB in government administration is as a guide or guide for the government or state administration officials in the context of good governance. ${ }^{15}$

Law Number 30 of 2014 concerning Government Administration is necessary for all parties, both the government, the community, and administrative court or Pengadilan Tata Usaha Negara (PTUN), with different interest factors, but overall, they have one thing in common: improving good governance. In addition to being based on laws and regulations, government administration is also based on the AAUPB, both those included in the legislation and judges' decisions that have permanent legal force and government practices. General principles of good governance have developed into discourses used as studies by scholars, which shows that AAUPB is an open concept (open begrip). It will develop and adjust to the space and time this concept is located as an open concept. On this basis, it is not surprising that the AAUPB contemplatively and in its application are different from one another.

\section{4. e-Government}

According to the World Bank, e-Government is defined as "The use/utilization of information technology by government agencies to improve services to the public, business people, and at the same time facilitate collaboration with other government agencies". Furthermore, according to the World Bank, e-Government must empower the community through broad access to the available information. Based on the above definition, e-Government has a reasonably broad scope or scope, covering all units within a government organization and its work partners (stakeholders).

1. Employees/Employees of the Government Institution

2. Community Members

3. Business People

4. Other Government Institutions

5. Suppliers/suppliers of office equipment and so on. In the concept of e-Government, the five types of partners interact with government agencies through information systems/computer networks.

E-Government is not a concept that can simply be implemented or applied. The implementation of e-Government requires Business Process re-engineering and organizational structure. Many writers and consulting agencies have tried to design the new organizational model/form. Still, a standard form has not been found that can be used in all existing government organizations. This is due to the uniqueness of each organization in terms of structure, core business, and stakeholders. The form/model of e-Government proposed by the PeopleSoft Consulting Division presented in this paper is a national-scale e-Government model. In this model, a government that wants to transform itself into a form of e-Government must have the following components. ${ }^{16}$

1. Executive Leadership

The leadership function in the national e-Government program rests on the shoulders of the head of government, who is tasked with setting the general goals and objectives of the national e-Government program and setting technology standards that every government agency must use under his control. The Chief Executive

\footnotetext{
${ }^{15}$ Solechan Solechan, “Asas-Asas Umum Pemerintahan Yang Baik Dalam Pelayanan Publik,” Administrative Law and Governance Journal 2, no. 3 (2019): 541-57, https://doi.org/10.14710/alj.v2i3.541-557.

${ }^{16}$ Putera, "E-Government Dan Reformasi Birokrasi Dalam Rangka Peningkatan Pelayanan Publik Di Daerah."
} 
Officer, who is played by the head of government/state, can delegate some of his authority to a government official who acts as a Chief Information Officer who carries out and oversees the day-to-day operations of the national e-Government program.

2. Participation of the Legislative Authority and other Authorities based on Jurisdiction. Representatives of the legislature must be included as government partners in supervising and directing e-Government programs nationally and regionally. Representatives of government agencies also need to be included considering they are the ones who represent the person in charge of e-government operations in each agency.

3. Information Technology Advisor (IT Advisor)

An institution that acts as a thinker on information technology issues (IT Think Tank) needs to be established or established. The institution's function is to provide technical advice and input in development to government agencies that run the program.

4. Enterprise Level Governance Boards

Responsible for application and infrastructure investment in each institution.

5. Technical Oversight Boards and supervisors

Responsible for the operation and readiness of the information system network and the consistency of application work.

Some of the benefits expected from implementing the E-Government concept seen from various sides include the following.

1. In terms of institutions, the expected benefits from institutions or organizations include cost savings in serving the community that arises due to paperless transactions, office automation and time, and the increased government agencies' capabilities in exchanging information and data (information sharing).

2. From the community (consumer) side, the benefits that are expected to be received by the community are in the form of faster service and information provision, fast access to electronic documents and forms, continuous community service ( 24 hours a day), increased ability to serve oneself service), increased ability to search for information, expanded access to information, and so on. ${ }^{17}$

\section{Digital Bureaucracy and Good Governance}

Sixteen years we have entered the 21 st century. A century that offers us both opportunities and challenges. Many changes have occurred. The taps of democracy that were previously closed are now wide open. The 1998 reform wave coincided with this new century, ushered us into a brighter future.

One of the things that marked the Reformation era was the echo of the discourse of good governance. This discourse was born as a form of shared desire to present good governance. Various government processes, both in terms of public policy formulation, implementation of development, implementation of the government's public bureaucracy, are expected to run transparently, effectively, and efficiently to improve people's welfare.

The term "governance" was first introduced in the 14th century in France. At that time, governance was still interpreted very simply. It is defined as the seat of government (the seat of government). However, gradually, the term became very popular when the world bank published the World Bank Report in 1989. The concept of good governance emphasizes the implementation of a stable and responsible state government and efficient and effective. In

17 Adi Cahyadi, "E-Government: Suatu Tinjauan Konsep Dan Permasalahan," The Winners 4, no. 1 (2003): 1, https://doi.org/10.21512/tw.v4i1.3796. 
addition, good governance maintains a synergistic constructive interaction between the state, the private sector, and the community.

In Indonesia, because good governance appears as a concept to be realized, of course, it has principles that must be achieved. Therefore, the government has formulated the principles of good governance through Government Regulation No. 101 of 2000, which contains the principles of good governance. ${ }^{18}$

The first principle, professionalism. Good governance must improve the ability and morale of government administration to provide accessible, fast, precise services at affordable costs.

The following principle, accountability. Good governance must increase the accountability of decision-makers in all areas that concern the public interest.

The third principle, transparency. Good governance must create mutual trust between the government and the public by providing information and ensuring the ease of obtaining accurate and adequate information.

After transparency is excellent service, good governance requires implementing public services that include reasonable procedures, transparent tariffs, legal certainty, ease of access, completeness of facilities and infrastructure, and friendly and disciplined services.

The following principle, democracy and participation. Good governance will encourage every citizen to exercise the right to express opinions in the decision-making process, which concerns the community's interests, either directly or indirectly.

The sixth principle, efficiency and effectiveness. Good governance must ensure the implementation of services to the community by using the available resources optimally and responsibly.

The whole society can accept the last principle, the rule of law and. Good governance, of course, must realize the existence of fair law enforcement for all parties without exception, uphold human rights and pay attention to the values that live in society.

However, good governance is not a concept that was born and can be realized by itself. Good governance is born and is realized on the pillars that support the development of good governance. Three main pillars support the ability of a nation to implement good governance. The three pillars include the government sector (the state sector), the community sector (the society sector), and the private sector.

In Presidential Regulation No. 81 of 2010 concerning the Grand Design of Bureaucratic Reform 2010-2025, it is deemed necessary to accelerate the achievement of good governance and reform the bureaucracy in all ministries/institutions/local governments. And the targets in this presidential regulation are:

1. The realization of a clean government and free of Corruption, Collusion, and Nepotism or Korupsi, Kolusi, dan Nepotisme (KKN)

2. The realization of improving the quality of public services to the community

3. Increased capacity and accountability of bureaucratic performance ${ }^{19}$

By 2025, it is hoped that good governance has been realized with a professional government bureaucracy, has high integrity, and becomes a public service and becomes a public service and a servant of the state. And the desired bureaucratic conditions are:

- The number of proportional civil servants

- Clean government and free of KKN

- Improving the quality of public services

- Capacity building and accountability of bureaucratic performance

- Increasing the professionalism of the human resources of the apparatus

${ }^{18}$ Cahyadi.

${ }^{19}$ Peraturan Presiden No. 81 tahun 2010 mengenai Grand Design Reformasi Birokrasi 2010-2025. 
- Increasing the mobility of the apparatus between regions, between the centre, and between the centre and the regions

- Increase in salary and welfare insurance.

\section{Public Service and Good Governance}

The ideals of independence, as stated in the fourth paragraph of the Preamble to the 1945 Constitution of the Republic of Indonesia, namely to protect the entire Indonesian nation and all of Indonesia's bloodshed, and to promote public welfare, educate the nation's life and participate in carrying out world order. based on freedom, lasting peace, and social justice keadilan $^{20}$

These four great ideals, we believe, will only be realized if our governance is good; professional, accountable, transparent, participatory, effective, efficient, and upholds the rule of law. That is the form of good government.

The three pillars have their respective roles. The government (legislative, executive, and judicial) plays a role in running and creating a conducive political and legal climate and other elements in governance. Entrepreneurs play a role in job creation. Society plays a role in creating social, economic, and political interactions. ${ }^{21}$

Osborne and Gaebler, in Reinventing government (1992) stated, the new paradigm of government will shift the role it plays. From those who used to play a direct role as a public service provider (rowing) and were involved in operational, technical activities to fulfil public needs, their role shifted to the steering function. The government still provides various public services but does not have to be directly involved with the production process. The government focuses more on providing direction, while the production of public services is left to the private sector and/or the third sector (non-governmental organizations). This function requires the government to empower the community by encouraging participation in the provision of public services. $^{22}$

The last factor, the digital bureaucracy, will present local information so that internet use in public services will enable local and global community competition. The internet can be a medium for disseminating various government information, campus information, local tourism potential, and so on, further increasing the institution's competitiveness. ${ }^{23}$

Then it will be able to increase the competitiveness of the institution.

Based on these three factors, the digital bureaucracy will deliver public services to the essential characteristics that good governance should have. All public service processes can be accessed by all citizens in an integrated manner quickly through information and communication technology. The goal is also not kidding; the digital bureaucracy presents good governance, where government services are transparent, accountable, and free of corruption.

That way, through the digital bureaucracy, the dream of realizing good governance in Indonesia is becoming more accurate.

The Bandar Lampung City Government made innovations to improve services to the community in managing resident documents. One example of a digital bureaucracy is an online service application for the people sitting sweet (Permen Manis) located at the Office of Occupation and Civil Registration (Disdukcapil) of Bandar Lampung City. In the application, there are services for making population documents such as Family Identity Cards or Kartu Keluarga (KK), KK Repairs, printing birth certificates, marriage, divorce, death, moving letters, including Identity Card or Kartu Tanda Penduduk KTP and Children Identity Card or Kartu Identitas Anak (KIA).

\footnotetext{
${ }^{20}$ Undang-Undang Dasar 1945

${ }^{21}$ Laoly, Birokrasi Digital.

22 Osborne D and Gabler T, Reinventing Government: Mentransformasi Semangat Wirausaha Kedalam Sektor Publik (Canada: Addison-Wesley Publiching Company, 1992).

${ }^{23}$ Laoly, Birokrasi Digital.
} 
With this application, it is hoped that it will make it easier for the community, improve services to the community and reduce KKN practices. So people no longer need to go back and forth to the Disdukcapil office of Bandar Lampung City to take care of population administration documents.

\section{Application of the Digital Bureaucracy System for the Department of Population and Civil Registration Bandar Lampung City}

The application of the digital bureaucracy system of the Department of Population and Civil Registration or Dinas Kependudkan dan Pencatatan Sipil (Disdukcapil) of Bandar Lampung City, an online community service called Pelayanan Online Masyarakat Duduk Manis (Permen Manis) received a positive response from its users. ${ }^{24}$ Because with this application, the community is greatly helped and does not need to bother coming and waiting at the Disdukcapil office, especially during the current pandemic. So people only need to download and then fill out the registration, make population documents, and immediately follow up by the Disdukcapil officer. According to the community, the application is the latest innovation to improve the quality of public services to realize an effective and efficient government. It is expected to continuously improve the quality of public services to help the people of Bandar Lampung City.

\section{Conclusion}

In line with theory, law, government, and society, the bureaucracy is expected to improve services to the community. The result will, of course, follow the process. However, whether or not we are successful in implementing good governance, we should depend on ourselves. There must be balance and mutual control among the three main pillars of development for the government, business actors, and the community.

Digital bureaucracy is an effort to realize good governance, namely a government expected to run transparently, effectively, and efficiently to improve people's welfare. Digital bureaucracy is expected to improve the quality of public services in a transparent, effective, and efficient manner.

The condition of the bureaucracy in Indonesia is currently moving towards good governance, marked by the start of a digital bureaucracy. One example is creating a community online service called Pelayanan Online Masyarakat Duduk Manis (Permen Manis), which is carried out by the Population and Civil Registration Service or Dinas Kependudukan dan Pencatatan Sipil (Disdukcapil) of Bandar Lampung City. So the public does not need to go back and forth to the Disdukcapil office. It is hoped to help the community make documents regarding population documents and reduce practices such as Corruption, Collusion, and Nepotism or Korupsi, Kolusi, dan Nepotisme (KKN).

\section{Bibliography}

\section{A. Journal}

Cahyadi, Adi. "E-Government: Suatu Tinjauan Konsep Dan Permasalahan." The Winners 4, no. 1 (2003): 1. https://doi.org/10.21512/tw.v4i1.3796.

Haripin, Muhammad, Chaula Rininta Anindya, and Adhi Priamarizki. "The Politics of CounterTerrorism in Post-Authoritarian States: Indonesia's Experience, 1998-2018." Defense \& Security Analysis 36, no. 3 (2020): 275-99. https://doi.org/10.1080/14751798.2020.1790807.

Hodge, B. J., William P. Anthony, and Lawrence M. Gales. Organization Theory: A Strategic

\footnotetext{
${ }^{24}$ Lampung Geh, “Terobosan Pelayanan, Disdukcapil Bandar Lampung Luncurkan Program 'Permen Manis.”’
} 
Approach. New Jersey: Pearson, 2003.

Hong, Sounman. "Representative Bureaucracy and Hierarchy: Interactions among Leadership, Middle-Level, and Street-Level Bureaucracy." Public Management Review 23, no. 9 (2021): 1317-38. https://doi.org/10.1080/14719037.2020.1743346.

McGoey, Linsey. "On the Will to Ignorance in Bureaucracy." Economy and Society 36, no. 2 (2007): 212-35. https://doi.org/10.1080/03085140701254282.

Murphy, Mark. "Bureaucracy and Its Limits: Accountability and Rationality in Higher Education." British Journal of Sociology of Education 30, no. 6 (2009): 683-95. https://doi.org/10.1080/01425690903235169.

Putera, Roni Ekha. "E-Government Dan Reformasi Birokrasi Dalam Rangka Peningkatan Pelayanan Publik Di Daerah." Demokrasi 8, no. 1 (2009): 97-98. https://media.neliti.com/media/publications/243823-e-government-dan-reformasibirokrasi-dal-06e88185.pdf.

Ryzin, Gregg G Van, Norma M Riccucci, and Huafang Li. "Representative Bureaucracy and Its Symbolic Effect on Citizens: A Conceptual Replication." Public Management Review 19, no. 9 (2017): 1365-79. https://doi.org/10.1080/14719037.2016.1195009.

Serpa, Sandro, and Carlos Miguel Ferreira. "The Concept of Bureaucracy by Max Weber." International Journal of Social Science Studies 7, no. 2 (2019): 12. https://doi.org/10.11114/ijsss.v7i2.3979.

Solechan, Solechan. "Asas-Asas Umum Pemerintahan Yang Baik Dalam Pelayanan Publik." Administrative Law and Governance Journal 2, no. 3 (2019): 541-57. https://doi.org/10.14710/alj.v2i3.541-557.

\section{B. Books}

D, Osborne, and Gabler T. Reinventing Government: Mentransformasi Semangat Wirausaha Kedalam Sektor Publik. Canada: Addison-Wesley Publiching Company, 1992.

Flynn, Norman. Public Sector Management. Chenai, 1990.

Gaffar, Affan. Politik Indonesia Transisi Menuju Demokrasi. Yogyakarta: Pustaka Pelajar, 2005.

Laoly, Yasonna H. Birokrasi Digital. Jakarta: PT.Pustaka Alvabet, 2016.

\section{Regulations}

The 1945 Constitution of Republic of Indonesia

Presidential Decree No. 80 of 2010 concerning Bureucratic Reform Grand Design

\section{Others}

Lampung Geh. “Terobosan Pelayanan, Disdukcapil Bandar Lampung Luncurkan Program 'Permen Manis."' Kumparan, 2021. https://kumparan.com/lampunggeh/terobosanpelayanan-disdukcapil-bandar-lampung-luncurkan-program-permen-manis1 vbonxeob41/full.

Yuniningsih, Tri. Kajian Birokrasi. Semarang: Departemen Administrasi Publik, Universitas Diponegoro, 2019. http://eprints.undip.ac.id/73483/1/BUKU_KAJIAN_BIROKRASI_GABUNGAN.pdf. 
